\title{
Regulation, Auditor Litigation and Settlements
}

August 2018. 


\begin{abstract}
This paper aims to understand the determinants of lawsuits against auditors in securities class action litigation and the settlement pattern by auditors when the suit is not dismissed. The issues we consider are: (i) when are auditors named as defendants (ii) when do auditors choose to settle and (iii) what proportion of the settlement do auditors pay in relation to the settlement by all the other parties; and (iv) differences in settlement strategies among the big-n firms. This paper also examines how the lawsuit and settlement patterns have changed following the enactment of major regulation such as the Private Securities Litigation Reform Act (PSLRA), Sarbanes Oxley Act (SOX). Following prior literature, we first establish that auditors are more likely both to be named and to settle in cases involving restatement of earnings, accusations of violation of GAAP or accounting improprieties. We then show that the likelihood of suit and settlement increase in a measure that we construct measuring the complexity of litigation. We then examine differences in settlement patterns across periods preceding and after the passage of PSLRA and SOX. We find that auditors are named less often in the post PSLRA period (relative to the pre-PSLRA period), settle with the same frequency in both periods but pay less proportional damages. The same set of comparisons show that auditors are just as likely to be sued post-SOX as pre-SOX, but settle with lower frequency and pay the same proportion of damages. Overall this study documents the beneficial role of both PSLRA and SOX on reducing the litigation burden on auditors. With regard to settlement strategies, we document the varying strategies employed by the Big-n firms that settle at different rates, vary in their aggressiveness and time to settle signaling the willingness to fight or cooperate in the settlement.
\end{abstract}




\section{Introduction}

One of the fundamental ideas underlying the Securities Acts of 1933-34 was to ensure an orderly flow of reliable information to financial markets. Among the different provisions adopted to ensure this uninterrupted flow were the creation of governmental bodies to regulate markets, primarily the SEC. Further requirements were that financial statements filed with the SEC be certified by an independent auditor, and statutes (section 10b-5 and section 11) that allowed investors to pursue auditors (and other financial intermediaries) in the event that the information disclosed to markets turned out to be inaccurate. The goal of this paper is to examine how ex-post litigation under Sections 10b-5 and 11 have affected auditors over a long period from 1995-2012.

The first point to note is that litigation has a significant impact on auditors especially the Big-4 who have faced threats of damages in the billions of dollars although actual settlements have been in the region of $1 \%$ of total revenues. This has become an area of interest for policy makers and public after the fall of Arthur Anderson in 2002, reducing the 'big five' accounting firms to 'big four'. ACAP (2008) documents through its survey of the big six largest auditing firms that they are defendants in ninety private actions related to audits of both private and public companies where the damage claims exceed $\$ 100$ million in each case of which forty one cases sought damages in excess of $\$ 500$ million, twenty- seven of these seeking damages in excess of $\$ 1$ billion and seven cases seeking damages over $\$ 10$ billion. In light of the damage claims, it is important to understand the litigation strategy of the audit firms and forces that drive the settlement.

The second point is that malpractice cases against auditors rarely go to trial because of the vast uncertainties associated with actual trials. ${ }^{1}$ An exception was Laventhol \& Howarth which

\footnotetext{
${ }^{1}$ The recent example of BDO Seidman vs. Esprito Santos is illustrative. BDO Seidman initially lost the case and Espritos Santos received a jury award of 521.7 million. In order to appeal, BDO had to post a bond of \$60 million.
} 
went bankrupt in 1990 while being the seventh largest American public accounting firm at the time. One of the reasons for the bankruptcy of Laventhol \& Howarth was its aggressive litigation strategy, preferring court action to settlement (Stiner, 2010). Settlements are easier for empirical analysis in that they are the final payment made in the case. In the rare instances when actual trials happen, the judgements are usually appealed in higher courts where they could be overturned resulting in settlements at a later date before the final verdict in the case is rendered. Given these facts, it makes sense to examine settlements in securities class action cases rather than trials. Consequently, we analyze all settlements made in cases filed under Sections 10b-5 and 11 of the securities acts over the period 1984-2011 to determine:

i. When auditors are named as a defendant in a class-action suit;

ii. When is the case against the auditor dismissed after the auditor is named (even though the case is pursued against the firm)

iii. The percentage of the total settlement paid by the auditor if the case against the auditor is not dismissed.

iv. Differences in settlement strategies among the big-n firms.

We also examine how the enactment of two major acts which affected the provision of audit services, (i) PSLRA (Public Securities Litigation Reform Act 1995) and (ii) SOX (Sarbanes Oxley Act 2002) have changed the patterns of settlement reached by auditors.

The process by which suits are initiated, pursued and settled involves many subtleties (P'ng, 1983). Our analysis examines whether factors such as the number and nature of plaintiffs and co-defendants affect the settlement by auditors. Further, we examine whether Big-5(n) firms differ systematically in their settlement patterns. In one of the first major empirical studies of

BDO won on appeal but further litigation is likely. If BDO had lost at this stage, they would have needed a bond of $\$ 500$ million to appeal further, an amount that would have bankrupted the firm. 
auditor litigation, Palmrose (1988) documented that one of the then Big-8 firms, Arthur Young, followed a very different strategy in terms of fighting rather than settling cases. As discussed earlier, almost no cases have gone to trial in recent years. However, the pattern of settlement seems to differ across auditors with $\mathrm{PwC}$ settling a significantly larger number of cases than the four other Big-5 auditors (Table 6a). Ernst \& Young settling for a lesser percentage of the total settlement in a significantly larger number of cases in comparison with the other big-n firms (Table 6b) and Deloitte not delaying its settlement after settlement by the company (usually the primary party in the case) is announced (Table 6c) $)^{2}$.

The theory underlying the settlement process in trials is studied in P'ng (1983). The main argument in that paper is that the settlement process is driven by the uncertainty in the legal system. Both Plaintiffs and Defendants try to use the uncertainty to drive a harder bargain. The ability to 'bluff' about willingness to go to trial is tested by both the parties. ${ }^{3}$ For example, if the auditor is reluctant to go to trial due to the perceived risks, the plaintiff attorney takes advantage of the situation to drive a hard bargain. The uncertainty in class action cases have been driven both by uncertainty about pleading standards and uncertainty about the size of damage awards. ${ }^{4}$ The other factor unique to auditors more than many other defendants in securities class action litigation is the number of times they are named as defendants usually by the same law firm representing the plaintiff. This repeated interaction provides an incentive for the auditor to build a reputation. One strategy is to never settle, so plaintiff law firms go after other easier targets. In this case it might

\footnotetext{
${ }^{2}$ In discussion we had with one of the CEO of a Big-4 firm, we gathered that litigation filed against the various offices is managed by a central office with counsel assisted by partner/s and support staff. This adds support to our analysis of litigation strategies at the firm level.

${ }^{3}$ The American judicial system provides incentives to the defendants to cooperate with the federal or state prosecutor through lesser penalty than if the defendant did not cooperate. Files (2012) finds that cooperation and forthright disclosure reduces the monetary penalties charged by the SEC. In this study the plaintiff and defendants are private parties and there is no such incentive for cooperation.

${ }^{4}$ One of the recommendations made in CCMR (2006) was to resolve the considerable uncertainty in application of Rule 10b-5 liability existing as a result of conflicting interpretations by courts.
} 
be rational to accept additional costs to fight in court so as to deter future lawsuits. Another factor, absent in P'ng (1983) but of importance given the long time period of our data, is evolving legal expertise. A small set of plaintiff law firms specialize in class action cases whereas legal consulting firms such as Cornerstone have developed models that help defend corporations and auditors. ${ }^{5}$ While specific twists and turns in the legal system affect settlement patterns, we are more generally concerned with systemic uncertainty. We hypothesize that as uncertainty decreases for some classes of defendant, they should be less willing to settle or to settle for smaller amounts.

In response to increasing litigation losses, the audit firms lobbied for tort reform. ${ }^{6}$ As a consequence of this lobbying as well as other factors, Congress enacted the PSLRA in 1995. Two important provisions in this act applying to auditors was the replacement of joint-and-several liability by proportional liability and a requirement to establish the merits of the suit at an early stage increasing the probability of summary dismissal. ${ }^{7}$ In the case of Adelphia that filed for bankruptcy in 2002 , losses claimed by investors were as high as $\$ 5.5$ billion. However, the settlement reached was for $\$ 455$ million, of which $\$ 210$ million was paid by the auditor Deloitte which audited the firm from the mid-1980's to 2002 . The remaining $\$ 245$ million was paid by 38 banks which underwrote stock offerings and extended syndicated loans to Adelphia (Bloomberg news, 2006). The establishment of a new standard of proportional liability coupled with a higher probability of dismissal was expected to lead to a lower number of suits Johnson et. al. (2007). Hillegeist (1999) examines the effect of alternate damage apportionment rules and finds that audit failure rate can decrease when there is a switch from a joint-and-several liability regime to

\footnotetext{
${ }^{5}$ Perhaps the most aggressive plaintiff law firm was headed by William S. Lerach; this law firm was eventually wound up.

${ }^{6}$ In the 1992 Statement of Position by the Big-6 firms at the time, the firms argued that: 'The principal causes of the auditing profession's liability problems are unwarranted litigation and coerced settlements...and... the principal cause of unwarranted litigation against the profession is joint-and-several liability" (Arthur Andersen et al. 1992).

${ }^{7}$ Another important provision for firms was a "Safe-Harbor" provision relating to forward looking disclosures.
} 
proportional liability rule. In addition, it may be expected to reduce the share of the damages paid by the auditor. While there were some initial changes in litigation rates, they proved to be temporary with securities class actions reverting to pre-PSLRA levels (or even higher Buckberg et. al (2005)). However, the number of dismissals also appeared to increase as shown in Table $1 \mathrm{~b}$ and documented in many studies. Apart from a conference presentation in Palmrose (2005), auditor in settlement has not, to our knowledge been examined in the prior literature. The reduction in (relative) risk for the auditor, should, in theory, lead to both a lower probability of settlement and a lower proportion paid by the auditor with regard to the total settlement. Our empirical results support both these hypotheses.

The second major regulatory event with regard to auditing was the enactment of SOX. The effect of SOX on settlement patterns are less clear from a theoretical perspective. First, SOX increased the scope of the audit imposing greater risk on auditors. However, it also required higher levels of due care and documentation both on auditors and on firms increasing audit quality. Both these possibilities have been advanced in earlier studies on SOX and they lead to opposite predictions with regard to settlement patterns. If the increased audit responsibilities make it easier to prove audit failure, we should expect to see both a greater probability and a greater level of auditor settlement. In contrast, if the audit quality increases, we should expect to see a lower probability of settlements. Since the provisions of SOX increased both the firm level controls and audit level controls, we would expect a less significant effect on settlement proportions. Our empirical results suggest that auditors are settling fewer cases in the Post-SOX era but are paying the same proportion of the total settlement as in the pre-SOX era.

We also control for the effects of accounting restatements and bankruptcy, two variable that have been shown to increase the probability and the amount of auditor settlements (Palmrose 
and Scholz (2004)). Consistent with prior studies we find that restatements and bankruptcy increase both the probability of the auditor settling the case and the proportion of the settlement paid by the auditor. While the analysis in terms of restatements is straightforward, the interpretation of the increased proportion in the case of bankruptcy could be attributable to a "deep pockets" effect where the auditors are allocated a greater proportion with settlements being held to similar levels as cases where the firm is not bankrupt or as a consequence of the fact that total damages are reduced due to the fact that the bankrupt firm cannot afford to pay large amounts while the auditor's share is held constant.

The next issue that we examine is whether there are significant differences in the settlement patterns across the Big-4. Palmrose (1988) documents that Arthur Young followed a different litigation strategy from the other seven (then Big-8) firms. We find that while the other Big-4 firms are indistinguishable, $\mathrm{PwC}$ has a statistically greater rate of settlement. The greater settlement rate could simply reflect a different bargaining policy rather than as a reflection on audit quality. Specifically, firms have to trade off the costs of defending themselves as compared with the cost of settling. As discussed in P'ng (1983) the optimal policy for the defendant is a mixed strategy of fighting some cases and settling others. The proportion depends on many factors including beliefs about what would happen should the case go to trial. Differences in settlement strategies are just as likely to arise out of perceptions of uncertainty in the legal system as they are to arise from the likelihood of audit failure.

The last issue that we examine is with regard to the complexity of the legal case. Greater complexity implies more uncertainty with regard to the ultimate outcome which will affect the settlement process and outcomes. We select five factors that are potentially related to the complexity of the case: (i) whether an institutional investor is a plaintiff; (ii) the number of 
plaintiffs; (iii) the number of other defendants, (iv) the number of institutions and (v) the class period. We use factor analysis to construct a single complexity measure out of these four variables. We then examine whether this factor affects the probability that the auditor will be named as a (codefendant), the likelihood that the auditor would settle and the proportional share paid by the auditor. As expected, both the likelihood of the auditor being named, and the likelihood of an auditor settlement increase with the complexity measure; however, the proportion paid by the auditor is unaffected by the complexity of litigation. The inference that we draw is that complexity, as in the comparison across pre and post-SOX periods, makes the auditor more willing to settle but does not differentially affect the level of settlement as compared with other defendants.

To our knowledge, this is the first study to examine carefully the fraction paid by the auditor with regard to the total settlement. By adding this variable to the analysis, we are able to contrast the changes in settlement patterns when comparing the pre and post PSLRA period as opposed to the comparison across pre and post SOX period. The probability that the auditor will be named as a defendant reduces in the post PSLRA period as does the proportion of damages paid by the auditor as may be expected by the shift from joint-and-several liability to proportional liability. In contrast, the comparison across pre and post SOX shows a significant reduction in the probability that the auditor will settle as may be expected by an increase in audit standards but it has an insignificant effect on the auditor being named as a defendant or the proportion of damages paid by the defendant. While these effects may not be directly attributable to the enactment of regulation, they are consistent with the changes in settlement patterns suggested by the theory due to the changes in perception of the risk associated with taking the case to trial. 
The rest of the paper is arranged as follows: Section 2 provides the literature review and hypothesis development; Section 3 discusses the data, variables used and the research design, while Section 4 discusses the results. The conclusions are provided in Section 5.

\section{Literature Review and Hypothesis Development}

Class action lawsuits has faced severe criticism, with many claiming it encourages frivolous lawsuit by lawyers who force the firm to settle for small amounts even when there is no merit to the case. On the other hand many see it as another form of regulation to curb bad behavior of managers. Park (2017) notes that auditors are part of the settlement in a third of the 200 largest securities class action settlement between the periods 1996 and 2007 and this is a higher percentage than all of the securities class action. We hypothesize that only cases that merit accusing auditors of shirking in their responsibility name auditors as defendants along with other parties in the case, leading us to the following hypothesis.

Hypothesis 1a: Accounting issues increases the probability of auditor being named in the securities class action lawsuit, the likelihood of auditor settling the lawsuit and paying a higher proportion of the settlement relative to all other parties settling the lawsuit.

Bankruptcy leaves the shareholders with very little recourse as the firm has very little money left if any after paying its creditors. This will lead them to turn to the auditors questioning whether they shirked on their fiduciary duty to properly inform the shareholders on the true financial condition of the firm. Shareholders will target the audit firm as one of the parties left with 'deep pockets' (Bar-Yosef and Sarath (2005)). This leads us to the following hypothesis. 
Hypothesis 1b: Bankruptcy of sued firm increases the probability of auditor being named in the securities class action lawsuit, the likelihood of auditor settling the lawsuit and paying a higher proportion of the settlement relative to all other parties settling the lawsuit.

One of the important measures adopted in PSLRA was to discourage these frivolous lawsuits, encourage institutional investors to bring cases, and appointment of lead plaintiffs. It also raised the standard for admissibility of the lawsuit and increased the chances of frivolous lawsuit to be dismissed early. However the regulation did not make any changes to the standards for settlement, however as discussed earlier it changed the method used for assessing damages to a proportional system. This leads us to hypothesize that-

Hypothesis 2: The enactment of PSLRA decreased litigation against auditors and the proportion of damages paid by auditors.

Similar to PSLRA, SOX legislation was not without its criticism, one of the major criticism was the increased cost associated with auditing a firm. The benefits of this cost was uncertain. DeFond and Francis (2005) question whether the radical reforms made in SOX were really needed and what the unintended consequences of the legislation are. The increased cost of auditing can be thought of in two ways. The additional amount charged was a insurance premium charged on a portfolio of firms audited against a few large future settlements. It could also be a cost for carrying out more work in the audit and keeping documentation for the work performed. This would lead to a higher quality audit and reduce the chances of settlement in the future. We test the following hypothesis stated in the alternate form.

Hypothesis 3: The enactment of SOX decreased the probability of auditor settlement.

As discussed earlier litigation strategy by the various firms would be different, some might choose to fight every case providing a signal to the market. We examine the settlement strategy of 
the audit firms and test if there is variation in the settlement rates, settlement ratio or time to settle compared to other firms leading us to

Hypothesis 4: There is variation in the litigation strategy among the big-n audit firms

\section{Data and Research Design.}

\subsection{Sample Selection}

Data on auditor litigation and settlement are culled from many sources for lawsuits filed between 1986 and $2011^{8}$. Woodruff-Sawyer litigation database, settlement agreements, Stanford class action alert, and the popular press. We do not include lawsuits that are active or related to private companies, not-for-profit organizations and mutual funds to isolate securities law violations related to only financial reporting. Our final sample has 2503 class action lawsuits. In 358 of these lawsuits auditor is named as a party to the litigation. Table 1a provides the various dimensions of the data used for different analysis. Of the 358 cases where auditors are named, auditors settle for varying amounts in 166 of the cases. For a separate analysis we take the largest 56 settlements that were settled by the auditor for more than $\$ 10$ million. Kaplan and Williams (2013) uses a similar method for data collection, but restrict their analysis to only financially distressed firms. The sample size if we adopt the restrictions is comparable. Talley (2006) also uses a similar method for data collection to understand the probability of a cataclysmic liability among big four auditors. The sample we have collected is comparable if we take into consideration the time period of the sample.

\footnotetext{
${ }^{8}$ Other current papers studying securities class action eg. Kempf \& Spalt (2018) also use data ending in 2011, as it is the last year in which reliable data is available in litigation datasets.
} 
Table $1 \mathrm{~b}$ provides the distribution of the sample over the years. In the early periods there are only a few cases. 19 percent of the cases are in the pre-PSLRA period before the enactment of PSLRA at the end of 1995.

Table 1c provides the distribution of the cases by industry based on the two digit SIC code. We list the largest 17 industries which had at least five cases where the auditor was named.

Table 2 provides descriptive statistics of the sample. The average settlement in class action litigation is $\$ 21.7$ million which is comparable to the average settlement by the auditor of $\$ 19.7$ million, however the sample sizes are vastly different. There are many cases where the auditor is not named or does not settle. The average time between filing of the lawsuit and the first settlement, usually by the company is about 2.16 years. We hand-collected the dates of the settlement by the auditor from settlement agreements and news reports for settlements larger than $\$ 10$ million by the auditor and we find that in a few cases the settlement by the auditor is around the time of the settlement by the company. However in many instances auditors settle after becoming aware of the total settlement of the company. The average time between the settlement by the company and the auditor is 463.58 days. The average class period is 174.16 days and extends to a median value of close to a year. This provides a window into the bargaining game played by the parties.

\subsection{Variables}

We use a set of accounting variables to understand the importance of accounting issues in the probability of the auditor being named, settles and the proportion of the settlements. The three accounting variables used are one, SEC investigation. SEC investigations is one, if there was a SEC investigation unrelated to the filing of the case but based on the details in the case. It is zero, 
otherwise. Earnings restatement is one if there was a earnings restatement around the time of the filing of the lawsuit, zero otherwise. These earnings restatements are the ones classified as intentional misstatements. Hennes, Leone and Miller (2008) document that there was only one restatement that was classified as in error according to their classification that resulted in class action lawsuit while a majority of the restatements classified as intentional resulted in class action litigation. We have a dummy variable that equals one if there are accounting issues or GAAP violations, zero if there is no allegation of accounting improprieties or GAAP violations.

We have the next set of variables to understand the differential effect of regulation such as SOX and PSLRA on auditor being named as a party to the case, auditor settling the case and the proportion of the auditor settlement to the total settlement. We have a dummy of one if the lawsuit was filed on or after the $23^{\text {rd }}$ of December 1995 for PSLRA and $30^{\text {th }}$ of July 2002 for SOX. Earlier periods are coded as zero.

We then have three variables that indicate the difference in lawsuits that auditors face most commonly. The first is bankruptcy which take a value of one if the firm that is the subject of the lawsuit declares bankruptcy before or soon after the filing of the lawsuit, zero otherwise. Section 11 and rule 10b-5 lawsuits have different standards of proof under PSLRA. In simple terms there was no change in section 11 lawsuit which is based on misleading disclosure related to securities issue in the pre and post PSLRA periods. However, Rule 10b-5 lawsuits were the focus of the PSLRA and the law was aimed at reducing those lawsuits. It is important to consider that section 11 lawsuit can only be made in cases alleging misleading disclosure related to a securities issue. So some section 11 cases also involve rule 10b-5 allegations.

The factors that contribute to complexity of litigation is measured by number of institutions bringing the case, if case is taken to court by an institutional investor, number of law firms 
representing the plaintiff, number of defendants other than the auditor and the class period. We conduct factor analysis and report one litigation complexity factor. Many of these variables are shown to be important in prior literature. All variables load in the expected direction, and the single factor explains $88.75 \%$ of the total variation of the five factors (eigenvalue of 1.105 ). Our results are qualitatively similar even if we include all these variables in the multivariate analysis.

\subsection{Research design}

We conduct our analysis in three stages. In the first analysis we take all the lawsuits filed for which we have the necessary information and exclude only the cases that are still active in court. The first variable of interest for us is Auditor Named which is one if the auditor is named in the lawsuit, zero if the auditor is not named. In the second analysis we only take cases where the auditor was named in the litigation and have the variable Auditor Settled which takes on a value of one if the auditor eventually settled, zero otherwise. The last step is to understand the proportion of the payment made the auditor to the total settlement by all parties. The total settlement by all parties is in many cases different from the settlement amount listed in many of the datasets. We go through news sources and settlement agreements to correctly compute the total settlement paid by all parties.

To conduct the first analysis, we take all cases that were later dismissed or settled to understand the probability of the auditor being named as one of the parties to the case. We run a logit regression with Auditor Named as the dependent variable and understand the effect of accounting variables (SEC investigation, Earnings restatement, accounting issues or GAAP violations). Regulatory dummies for PSLRA and SOX. Dummies of lawsuit characteristic (Bankruptcy, Section 11, Rule 10b-5). We also include the complexity factor obtained from the 
factor analysis of five factors detailed in the previous section. We expect the accounting variables to be significant consistent with Hypothesis 1a. to indicate that auditors are named when there is are problems related to the accounting or auditing at the firm. We expect the post PSLRA dummy to be significant indicating that more meritorious cases were made before the court due to the heightened pleading standards consistent with hypothesis $2^{9}$. In bankruptcy cases the plaintiff lawyers know they would not be able to recover much from the firm that is going through bankruptcy and so will have to recover the damages from the auditor or other parties who had a fiduciary duty to inform the public in a timely fashion the impending financial problems at the firm. This is consistent with hypothesis $1 \mathrm{~b}$. Section 11 lawsuit as we discussed earlier did not change much in the post PSLRA period and so we expect the auditors to be named with a higher probability. We expect the complexity factor to be significant based on prior literature that has shown that the auditor is likely to be named when the class period is larger, when an institutional investor takes the firm to court. We have three models, the first one includes both the SOX and PSLRA dummies. Because of difficulty in interpreting interaction effects in a logit regression we conduct two separate analyses in which we include only one of the regulatory dummies in each of the regression. We follow the same methodology in all our analysis.

The second analysis is similar to the one above but only includes the sample where auditor is named and discards the remaining sample. We call this the Auditor Settled which takes on a value of one if the auditor eventually settled, zero otherwise. The logit regression is similar to the one above. Here we expect the auditor to settle only when there is merit to the case i.e. there are

\footnotetext{
${ }^{9}$ Consistent with the Act's objective, Johnson, Nelson and Pritchard (2002), find evidence that accounting and insider trading variables explain the filing of post-PSLRA SCA lawsuits but are insignificant in the pre-PSLRA period, suggesting that PSLRA discouraged frivolous lawsuits. In examining the details of the lawsuits post-PSLRA, Perino (2003) finds the overall case quality improvement to be statistically significant. Choi, Nelson and Pritchard (2009) also find that pre-PSLRA nuisance claims are less likely to be filed under the PSLRA regime. Krishna Moorthy (2012) finds a higher turnover of CEOs in the securities class action sample studied indicating more meritorious lawsuits being admitted in court following the passage of PSLRA.
} 
accounting issues as maintained in hypothesis 1a. We expect SEC investigation, earnings restatement and accounting issues or GAAP violations to result in settlement by the auditor. We expect settlement in the post-SOX period to be less because of the many procedures and checks placed on the auditor. This in turn has improved the audit quality and reduced the chances of the auditor to be found at fault. Hence we expect the variable to negatively related to settlement consistent with hypothesis 3 . This provides for the evidence that auditors in employing greater procedures and checks on internal control incur a greater cost in conducting the audit but suffer lesser damages from lawsuit. We do not expect any effect on PSLRA as the laws was intended to reduce the number of frivolous lawsuits and had no effect on the settlements. We do not expect auditors to settle in a greater or lesser proportion in bankruptcy cases, section 11 lawsuit or rule 10b-5 lawsuits.

In the next analysis we are interested in understanding the proportion of the payment made by auditors to total class action settlement paid by all defendants including the auditors. We are interested in understanding the effectiveness of the change in PSLRA from joint and several liability to proportional liability which the auditors lobbied before and during the passage of PSLRA. .

We include an additional factor of the time period between filing and settlement to understand if there was any effect on the settlement. It is assumed that early settlements are settled for a lesser amount, but long drawn out cases cost more for both the parties and the disagreements are greater leading to larger settlement amounts. Section 11 lawsuit damages are capped and are less severe than in 10b-5 lawsuits. Due to difficulty of obtaining dates of smaller settlements by auditors we restrict our analysis in the next step to only 56 cases where the settlement by the auditor 
was larger than $\$ 10$ million. We are interested in understanding if there is prolonged negotiation and bargaining when auditor pays a greater proportion of the settlement.

\section{Empirical Results}

\subsection{Multivariate Analysis}

Table 3 shows the results of the logistic regression estimating the probability of auditor being named in the securities class action lawsuit. In panel 1, we find the probability of auditor being named in the lawsuit increases by $11 \%$ and $13 \%$ following restatement of earnings and accounting improprieties or violations of GAAP respectively, holding other variables at their median. This result is consistent with hypothesis $1 \mathrm{a}$ and provides further evidence that class action lawsuit against auditors are based on serious accounting problems at the firm. We find the probability of auditor being named decreases by $11 \%$ following passage of PSLRA, consistent with hypothesis 2 . We also find that the probability of auditor being named in cases of bankruptcy cases increases by $8.5 \%$ consistent with hypothesis $1 \mathrm{~b}$. We also find that the probability of auditor being named in section 11 cases relating to issuance of security increases by $7 \%$. The probability of auditor being named increases with the complexity of litigation variable we devised for the study.

Table 4 provides results of the logistic regression on the probability of the auditor settling the case, once named. Here we find the probability of the auditor settling increases by $14 \%$ and $18 \%$ when there is restatement of earnings and accounting issues or violation of GAAP respectively consistent with hypothesis $1 \mathrm{a}$. The most interesting finding is that the probability of 
settling decreases by $13.1 \%$ following the passage of SOX, consistent with hypothesis 3 . We interpret the result as indirect evidence of improvement in audit quality following the passage of SOX. The additional steps taken by the auditors and the firm provides greater documentation to support the work carried out. This provides greater evidence against the auditor being at fault reducing the likelihood of settlement. Consistent with other studies that have shown greater settlement rates when case is handled by an institutional investor, or when the class period is long, we find that the chance of auditors settling is higher in complex litigation. The results are also consistent with Donelson and Prentice (2012) examine 144 cases filed between 1996 to 2005 where auditors were named as defendant and examine factors affecting settlement by auditors for more than $\$ 5$ million and find that restatements, high audit fees and SEC enforcement were significant in explaining auditor settlements.

Table 5a examines the determinants of the percentage of total settlement paid by the auditor. The results show that lesser percentage is paid by the auditor following the passage of PSLRA. One of the provisions as it related to auditors was the change from joint and several liability to one of proportional liability. However we find that the proportion paid in bankruptcy cases is higher. This could be due to one of two reasons, either the damages assessed on the auditor are the same regardless of whether the company went bankrupt or not. However the bankrupt company is not able to pay the damages it is supposed to pay. This reduces the denominator making the ratio higher. It could also be that the shareholders suffered damage due to the auditor not reporting the true financial condition in a timely fashion. This might make the Judge or other party apportion a higher than normal proportion of the damage on the auditor making the proportion paid by the auditor. We also find that the auditor is responsible for a lesser percentage of the total settlement in section 11 lawsuits. Table $5 \mathrm{~b}$ extends the analysis to include only cases that were 
settled for more than $\$ 10$ million and includes an additional variable measuring the time between settlements in the securities class action by the company to the settlement by the auditor. This indicates resolution of some of the uncertainties in the case as the settlement by the company which is usually the major party. We find in cases where the percentage share of the total settlement by the auditor is high, the time taken by the auditor to negotiate a settlement is greater indicating both parties driving a hard bargain. The sample is restricted to only large settlements in this analysis because of the difficulty in obtaining the dates (usually from news reports) of the settlement when the settlement by the auditor is less than $\$ 10$ million. Also, since this analysis only included large settlements by auditor, the correlation between Accounting issues or GAAP violations and SEC investigation is very high and hence the variable Accounting issues or GAAP violations is excluded in the analysis.

\subsection{Univariate Analysis of differential settlement strategies of Big-n firms}

We perform chi-square test on each of the five big-5 firm settlements during our sample period. We document the variations in strategies of the big-5 firms. To make the analysis easier we group firms that merged later as part of one of the big-5 firm.

In Table 6a, we find that $\mathrm{PwC}$ settles a significantly larger proportion of the cases compared to the rest of the big-4 firms. PwC settled 44 of the 69 cases it was involved in, however the rest

of the firms together settled only 121 of the 289 cases they were involved in. This difference in ratio is significant at the $1 \%$ level. Table $6 \mathrm{~b}$ examines the ratio of Ernst \& Young settlements to total settlement by all parties in the case. The table shows Ernst \& Young settles 19 cases paying a lesser percentage than the median in majority of the 25 cases they were named. In comparison other firms pay above median percentages in 77 of the 141 cases. This difference is significant at 
the $1 \%$ level. Finally in Table $6 \mathrm{c}$ we examine the delay in settlement by the auditor after the announcement of settlement by the company in the securities class action lawsuit. Deloitte delays settlement above the median time to settle in 2 of the 10 cases where the settlement is above $\$ 10$ million. In comparison other firms delay settlement in 26 of the 46 cases. The difference in ratio is significant at the $5 \%$ level.

\section{Conclusion}

This paper examines auditor litigation and settlements over the entire data period stretching from 1985-2014. While earlier studies have examined portions of these periods, the study of the entire period allows us to draw some interesting inferences on long-term shifts in settlement patterns. In addition, we analyze the proportion of the total settlement paid by auditors, a factor that is absent in earlier studies.

We show that the changes in litigation settlements across the pre and post PSLRA period exhibits a different pattern when compared with the changes across the pre and post SOX periods. While the primary difference across pre and post SOX periods is a lower probability of settlement, the main difference in the pre and post PSLRA period is a decrease in the proportion of the settlement paid by auditors.

We also document that there are significant differences in settlement rates across the Big5 auditors. We conjecture that these differences may represent strategic choices in balancing actual and potential legal costs with the costs of settling the lawsuit. In addition, we show that the proportion of damages paid by the auditor in cases involving bankruptcy is significantly higher 
than in other cases. An interesting question we hope to address in the future is whether this is due to the fact that auditors are assessed a larger share of the penalty despite laws on proportional damages or whether the total settlements are smaller relative to the class damage when the firm goes bankrupt. 


\section{References}

Arthur Andersen, Coopers \& Lybrand, Deloitte \& Touche, Ernst \& Young, KPMG Peat Marwick, and Price Waterhouse. "The Liability Crisis in the United States: Impact on the Accounting Profession; A Statement of Position.”, New York, NY, 1992.

Ali, Ashiq, and Sanjay Kallapur. "Securities Price Consequences of the Private Securities Litigation Reform Act of 1995 and Related Events." The Accounting Review (2001): 431-60.

Bar-Yosef, Sasson, and Bharat Sarath. "Auditor size, market segmentation and litigation patterns: A theoretical analysis." Review of Accounting Studies 10.1 (2005): 59-92.

Bloomberg News. Deloitte and banks to pay $\$ 455$ million to Adelphia investors.” December 9, 2006.

Buckberg, Elaine, et al. "Recent trends in shareholder class action litigation: Bear market cases bring big settlements." NERA Economic Consulting-How Markets Work 16 (2005).

Committee on Capital Markets Regulation (CCMR). "Interim Report of the Committee on Capital Markets Regulation.” 2006.

Choi, Stephen J., Karen K. Nelson, and Adam C. Pritchard. "The screening effect of the private securities litigation reform act." Journal of Empirical Legal Studies 6.1 (2009): 35-68.

DeFond, Mark L., and Jere R. Francis. "Audit research after sarbanes-oxley." Auditing: A Journal of Practice \& Theory 24.s-1 (2005): 5-30.

Donelson, D. C., \& R. Prentice "Scienter Pleading and Rule 10b-5: Empirical Analysis and Behavioral Implications," Case Western Law Rev. 441. (2012). 
Hennes, Karen M., Andrew J. Leone, and Brian P. Miller. "The importance of distinguishing errors from irregularities in restatement research: The case of restatements and CEO/CFO turnover." The Accounting Review 83.6 (2008): 1487-1519.

Hillegeist, Stephen A. "Financial reporting and auditing under alternative damage apportionment rules." The Accounting Review 74.3 (1999): 347-369.

Johnson, Marilyn F., Karen K. Nelson, and Adam C. Pritchard. "Do the merits matter more? Class actions under the Private Securities Litigation Reform Act." Stanford Law and Economics Working paper, Stanford University, 2002.

Johnson, Marilyn F., Karen K. Nelson, and Adam C. Pritchard. "Do the merits matter more? The impact of the Private Securities Litigation Reform Act." Journal of Law, Economics, and Organization 23.3 (2007): 627-652.

Kaplan, Steven E., and David D. Williams. "Do going concern audit reports protect auditors from litigation? A simultaneous equations approach." The Accounting Review 88.1 (2012): 199-232.

Kempf, Elisabeth and Splat, Oliver. "Taxing successful innovation: The hidden cost of meritless class action lawsuits" University of Chicago working paper (2018).

Kinney, William R., Zoe-Vonna Palmrose, and Susan Scholz. "Auditor independence, nonaudit services, and restatements: Was the US government right?" Journal of Accounting Research 42.3 (2004): 561-588.

Krishna Moorthy, Lakshmana. "Changes in Corporate Governance following Allegations of Fraud against Shareholders versus Fraud against the Government." Dissertation. University of Minnesota, 2012. 
P'ng, Ivan PL. "Strategic behavior in suit, settlement, and trial." The Bell Journal of Economics (1983): 539-550.

Palmrose, Zoe-Vonna. "1987 Competitive Manuscript Co-Winner: An analysis of auditor litigation and audit service quality." Accounting review (1988): 55-73.

Palmrose, Zoe-Vonna. "Maintaining the Value and Viability of Independent Auditors as Gatekeepers Under SOX: An Auditing Master Proposal, Brookings -Nomura Seminar: After the horses have left the barn: The future role of financial gatekeepers." (Sept. 28, 2005).

Park, James J. “Auditor settlements in securities class actions.” Journal of Empirical Legal Studies, 14(1), (2017): 169-198.

Perino, M. "Did the Private Securities Litigation Reform Act work?" University of Illinois Law Review (2003): 913-977.

Pritchard, Adam C., and Hillary A. Sale. "What counts as fraud? An empirical study of motions to dismiss under the Private Securities Litigation Reform Act." Journal of Empirical Legal Studies, 2(1), (2005): 125-149.

Stiner, Frederic M. "Bankruptcy of an Accounting Firm: Causes and consequences of the Laventhol \& Horwath Failure.” Economic \& Business Journal: Enquiries \& Perspectives, 3 (1), (2010), 1-15.

Talley, Eric L. "Cataclysmic Liability Risk Among Big Four Auditors." Columbia Law Review (2006): 1641-1697. 
Table 1a Sample Description

Securities class action litigation filed between 1984

to 2011

Auditor named in litigation

2503

Auditor settles in litigation

358

Auditor settles for more than \$10 Million

166

56

Table 1b Sample size by year

\begin{tabular}{|c|c|c|}
\hline Year & All class action & Auditor named \\
\hline 1984 & 2 & 1 \\
\hline 1985 & 1 & 0 \\
\hline 1986 & 1 & 0 \\
\hline 1987 & 2 & 2 \\
\hline 1988 & 5 & 2 \\
\hline 1989 & 13 & 3 \\
\hline 1990 & 31 & 4 \\
\hline 1991 & 17 & 4 \\
\hline 1992 & 30 & 8 \\
\hline 1993 & 65 & 12 \\
\hline 1994 & 170 & 22 \\
\hline 1995 & 140 & 11 \\
\hline 1996 & 82 & 9 \\
\hline 1997 & 140 & 19 \\
\hline 1998 & 190 & 35 \\
\hline 1999 & 163 & 22 \\
\hline 2000 & 163 & 23 \\
\hline 2001 & 375 & 22 \\
\hline 2002 & 169 & 43 \\
\hline 2003 & 133 & 18 \\
\hline 2004 & 152 & 19 \\
\hline 2005 & 116 & 17 \\
\hline 2006 & 80 & 16 \\
\hline 2007 & 100 & 17 \\
\hline 2008 & 80 & 14 \\
\hline 2009 & 48 & 9 \\
\hline 2010 & 26 & 3 \\
\hline 2011 & 9 & 3 \\
\hline Total & 2503 & 358 \\
\hline
\end{tabular}


Table 1c Sample by industry

\begin{tabular}{|clcc|}
\hline $\begin{array}{c}\text { SIC- two } \\
\text { digit }\end{array}$ & \multicolumn{1}{c}{ Industry } & All class action & Auditor named \\
\hline & & & \\
73 & Business Services & 476 & 56 \\
35 & Industrial Machinery \& Equipment & 184 & 28 \\
36 & Electronic \& Other Electric Equipment & 251 & 26 \\
60 & Depository Institutions & 74 & 20 \\
49 & Electric, Gas, \& Sanitary Services & 62 & 18 \\
61 & Nondepository Institutions & 48 & 15 \\
63 & Insurance Carriers & 78 & 15 \\
50 & Wholesale Trade - Durable Goods & 61 & 14 \\
48 & Communications & 130 & 14 \\
28 & Chemical \& Allied Products & 208 & 13 \\
38 & Instruments \& Related Products & 117 & 11 \\
80 & Health Services & 63 & 10 \\
67 & Holding \& Other Investment Offices & 42 & 9 \\
37 & Transportation Equipment & 28 & 8 \\
59 & Miscellaneous Retail & 53 & 8 \\
87 & Engineering \& Management Services & 31 & 6 \\
58 & Eating \& Drinking Places & 21 & 5 \\
All other & & 576 & 82 \\
\hline & & 2503 & 358 \\
\hline
\end{tabular}


Table 2 Descriptive Statistics

\begin{tabular}{|c|c|c|}
\hline & Mean & Median \\
\hline Total settlement in class action & $\$ 21,700,000$ & $\$ 2,700,000$ \\
\hline Number of defendants & 6 & 5 \\
\hline Number of Plaintiff lawyers & 1.96 & 1 \\
\hline Class action period & 174.16 days & 349 days \\
\hline Number of institutions & 0.482 & 0 \\
\hline $\begin{array}{l}\text { Time between filing of case and first settlement } \\
\text { date }\end{array}$ & 792 days & 867 days \\
\hline Total Auditor Settlement & $\$ 19,700,000$ & $\$ 4,800,000$ \\
\hline $\begin{array}{l}\text { Auditor settlement / Total settlement by all parties } \\
\text { Time between auditor settlement and first } \\
\text { settlement in class action, only large settlements of } \\
\text { more than } \$ 10 \text { Million }\end{array}$ & 0.3989 & 0.2674 \\
\hline
\end{tabular}


Table 3 Results of logistic regression estimating the probability of auditor being named (Auditor Named) in the securities class action lawsuit based on accounting related variables, regulatory regime, complexity of litigation.

Dependent Variable - Auditor Named $(0,1)$

\begin{tabular}{|c|c|c|c|}
\hline Variables & (1) & (2) & (3) \\
\hline Intercept & $\begin{array}{l}-2.964 * * * \\
(0.281)\end{array}$ & $\begin{array}{l}-2.948^{* * *} \\
(0.279)\end{array}$ & $\begin{array}{l}-3.333 * * * \\
(0.285)\end{array}$ \\
\hline SEC Investigation & $\begin{array}{l}0.377 * * \\
(0.181)\end{array}$ & $\begin{array}{l}0.323 * \\
(0.177)\end{array}$ & $\begin{array}{l}0.385 * * \\
(0.176)\end{array}$ \\
\hline Earnings restatement & $\begin{array}{l}1.066 * * * \\
(0.148)\end{array}$ & $\begin{array}{l}1.102 * * * \\
(0.147)\end{array}$ & $\begin{array}{l}0.908 * * * \\
(0.140)\end{array}$ \\
\hline accounting issues or GAAP violations & $\begin{array}{l}1.837 * * * \\
(0.216)\end{array}$ & $\begin{array}{l}1.790 * * * \\
(0.211)\end{array}$ & $\begin{array}{l}1.844 * * * \\
(0.220)\end{array}$ \\
\hline Post-SOX & $\begin{array}{l}-0.247 \\
(0.153)\end{array}$ & & $\begin{array}{l}-0.452 * * * \\
(0.142)\end{array}$ \\
\hline Post-PSLRA & $\begin{array}{l}-1.027 * * * \\
(0.194)\end{array}$ & $\begin{array}{l}-1.136 * * * \\
(0.186)\end{array}$ & \\
\hline Bankruptcy & $\begin{array}{l}0.800 * * * \\
(0.169)\end{array}$ & $\begin{array}{l}0.825 * * * \\
(0.168)\end{array}$ & $\begin{array}{l}0.700 * * * \\
(0.165)\end{array}$ \\
\hline Section 11 lawsuit & $\begin{array}{l}0.733 * * * \\
(0.148)\end{array}$ & $\begin{array}{l}0.747 * * * \\
(0.147)\end{array}$ & $\begin{array}{l}0.643 * * * \\
(0.146)\end{array}$ \\
\hline Rule 10b-5 lawsuit & $\begin{array}{l}-0.0538 \\
(0.211)\end{array}$ & $\begin{array}{l}-0.0449 \\
(0.212)\end{array}$ & $\begin{array}{l}-0.404 * * \\
(0.203)\end{array}$ \\
\hline Complexity factor & $\begin{array}{l}0.400 * * * \\
(0.0710)\end{array}$ & $\begin{array}{l}0.380 * * * \\
(0.0693)\end{array}$ & $\begin{array}{l}0.354 * * * \\
(0.0685)\end{array}$ \\
\hline $\mathrm{N}$ & 2,503 & 2,503 & 2,503 \\
\hline Pseudo R-squared & 18.19 & 18.05 & 16.93 \\
\hline
\end{tabular}

Robust standard errors in parentheses $* * * \mathrm{p}<0.01, * * \mathrm{p}<0.05, * \mathrm{p}<0.1$ 
Table 4 Results of logistic regression estimating the probability of auditor settling (Auditor Settled) the case after being named in the securities class action lawsuit based on accounting related variables, regulatory regime, complexity of litigation.

Dependent Variable - Auditor Settled $(0,1)$

\begin{tabular}{|llll|}
\hline Variables & \multicolumn{1}{c}{$(1)$} & \multicolumn{1}{c}{$(2)$} & \\
\hline Intercept & & & \\
& & & \\
SEC Investigation & -0.911 & -0.925 & -0.937 \\
& $(0.575)$ & $(0.569)$ & $(0.571)$ \\
Earnings restatement & 0.319 & 0.207 & 0.317 \\
& $(0.296)$ & $(0.292)$ & $(0.295)$ \\
accounting issues or GAAP violations & $0.592^{* *}$ & $0.699^{* * *}$ & $0.565^{* *}$ \\
& $(0.252)$ & $(0.250)$ & $(0.241)$ \\
Post-SOX & $0.804^{*}$ & $0.808^{*}$ & $0.790^{*}$ \\
& $(0.465)$ & $(0.458)$ & $(0.467)$ \\
Post-PSLRA & $-0.534^{* *}$ & & $-0.564 * *$ \\
Bankruptcy & $(0.260)$ & & $(0.250)$ \\
Section 11 lawsuit & -0.141 & -0.391 & \\
& $(0.369)$ & $(0.354)$ & \\
Rule 10b-5 lawsuit & 0.249 & 0.274 & 0.230 \\
Complexity factor & $(0.276)$ & $(0.273)$ & $(0.269)$ \\
& 0.107 & 0.101 & 0.108 \\
Pseudo R-squared & $(0.243)$ & $(0.240)$ & $(0.243)$ \\
& -0.258 & -0.270 & -0.310 \\
& $(0.402)$ & $(0.400)$ & $(0.379)$ \\
& $0.352^{* * *}$ & $0.335^{* * *}$ & $0.344^{* * *}$ \\
& $(0.111)$ & $(0.111)$ & $(0.109)$ \\
\hline
\end{tabular}

Robust standard errors in parentheses. $* * * \mathrm{p}<0.01, * * \mathrm{p}<0.05, * \mathrm{p}<0.1$ 
Table 5a OLS regression of auditor settlement as a percentage of total settlement by all defendants on accounting related variables, regulatory regime, complexity of litigation.

Dependent Variable - \$ value of auditor settlement to the total settlement by all the parties in the litigation.

\begin{tabular}{|llll|}
\hline Variables & \multicolumn{1}{c}{$(1)$} & \multicolumn{1}{c}{$(2)$} & \multicolumn{1}{c|}{$(3)$} \\
\hline Intercept & & & \\
& & & \\
SEC Investigation & $\left(0.168^{* *}\right.$ & $0.268^{* *}$ & $0.263^{*}$ \\
& 0.0637 & $(0.127)$ & $(0.143)$ \\
Earnings restatement & $(0.0860)$ & $(0.0902)$ & $(0.0838)$ \\
& 0.0220 & 0.00985 & -0.0163 \\
accounting issues or GAAP violations & $(0.0626)$ & $(0.0583)$ & $(0.0605)$ \\
& 0.166 & 0.153 & 0.0915 \\
Post-SOX & $(0.160)$ & $(0.157)$ & $(0.180)$ \\
& 0.0825 & & 0.0308 \\
Post-PSLRA & $(0.0774)$ & & $(0.0711)$ \\
Bankruptcy & $-0.319^{* *}$ & $-0.285^{* *}$ & \\
Section 11 lawsuit & $(0.134)$ & $(0.121)$ & \\
& $0.354^{* * *}$ & $0.352^{* * *}$ & $0.309 * * *$ \\
Rule 10b-5 lawsuit & $(0.107)$ & $(0.106)$ & $(0.102)$ \\
Complexity factor & $-0.264^{* * *}$ & $-0.258^{* * *}$ & $-0.243^{* * *}$ \\
& $(0.0771)$ & $(0.0734)$ & $(0.0753)$ \\
Time between lawsuit filing and settlement & 0.130 & 0.131 & 0.0239 \\
& $(0.105)$ & $(0.103)$ & $(0.106)$ \\
& -0.0223 & -0.0223 & -0.0388 \\
& $(0.0282)$ & $(0.0289)$ & $(0.0271)$ \\
R & 0.0891 & 0.102 & 0.0438 \\
& $(0.0652)$ & $(0.0645)$ & $(0.0591)$ \\
\hline
\end{tabular}

Robust standard errors in parentheses. ${ }^{* * *} \mathrm{p}<0.01,{ }^{* *} \mathrm{p}<0.05,{ }^{*} \mathrm{p}<0.1$ 
Table 5b OLS regression of auditor settlement greater than 10 Million dollars (large settlement) as a percentage of total settlement by all defendants on accounting related variables, regulatory regime, complexity of litigation.

Dependent Variable - \$ value of auditor settlement greater than $\$ 10$ million to the total settlement by all the parties in the litigation

\begin{tabular}{|c|c|c|c|}
\hline Variables & (1) & (2) & (3) \\
\hline Intercept & $\begin{array}{l}0.0228 \\
(0.125)\end{array}$ & $\begin{array}{l}-0.0403 \\
(0.114)\end{array}$ & $\begin{array}{l}0.0890 \\
(0.114)\end{array}$ \\
\hline SEC Investigation & $\begin{array}{l}-0.00980 \\
(0.103)\end{array}$ & $\begin{array}{l}-0.00344 \\
(0.104)\end{array}$ & $\begin{array}{l}-0.00517 \\
(0.103)\end{array}$ \\
\hline Earnings restatement & $\begin{array}{l}-0.0330 \\
(0.0811)\end{array}$ & $\begin{array}{l}-0.0349 \\
(0.0853)\end{array}$ & $\begin{array}{l}-0.0295 \\
(0.0794)\end{array}$ \\
\hline Post-SOX & $\begin{array}{l}0.154 \\
(0.127)\end{array}$ & & $\begin{array}{l}0.160 \\
(0.123)\end{array}$ \\
\hline Post-PSLRA & $\begin{array}{l}0.0971 \\
(0.0920)\end{array}$ & $\begin{array}{l}0.149 * \\
(0.0865)\end{array}$ & \\
\hline Bankruptcy & $\begin{array}{l}0.342 * * * \\
(0.0908)\end{array}$ & $\begin{array}{l}0.297 * * * \\
(0.0875)\end{array}$ & $\begin{array}{l}0.351 * * * \\
(0.0878)\end{array}$ \\
\hline Section 11 lawsuit & $\begin{array}{l}-0.259 * * \\
(0.104)\end{array}$ & $\begin{array}{l}-0.211 * * \\
(0.0933)\end{array}$ & $\begin{array}{l}-0.268 * * * \\
(0.0963)\end{array}$ \\
\hline Rule 10b-5 lawsuiit & $\begin{array}{l}0.174 * * * \\
(0.0551)\end{array}$ & $\begin{array}{l}0.203 * * * \\
(0.0695)\end{array}$ & $\begin{array}{l}0.198 * * * \\
(0.0651)\end{array}$ \\
\hline Complexity factor & $\begin{array}{l}-0.0241 \\
(0.0449)\end{array}$ & $\begin{array}{l}-0.0230 \\
(0.0479)\end{array}$ & $\begin{array}{l}-0.0209 \\
(0.0418)\end{array}$ \\
\hline Time between lawsuit filing and settlement & $\begin{array}{l}0.0123 \\
(0.0715)\end{array}$ & $\begin{array}{l}0.0459 \\
(0.0721)\end{array}$ & $\begin{array}{l}0.00762 \\
(0.0701)\end{array}$ \\
\hline $\begin{array}{l}\text { Time between settlement by auditor and the first } \\
\text { settlement in the class action }\end{array}$ & $\begin{array}{l}0.140 * \\
(0.0743)\end{array}$ & $\begin{array}{l}0.124 \\
(0.0781)\end{array}$ & $\begin{array}{l}0.139 * \\
(0.0738)\end{array}$ \\
\hline $\begin{array}{l}\text { Observations } \\
\text { R-squared }\end{array}$ & $\begin{array}{c}56 \\
0.366\end{array}$ & $\begin{array}{c}56 \\
0.329\end{array}$ & $\begin{array}{c}56 \\
0.363\end{array}$ \\
\hline
\end{tabular}

Robust standard errors in parentheses. $* * * \mathrm{p}<0.01, * * \mathrm{p}<0.05, * \mathrm{p}<0.1$ 
Table 6a Results of Chi-Square test showing the difference in settlement strategies of PwC compared to other big-n firms.

\begin{tabular}{|l|l|l|l|l|}
\hline \multicolumn{5}{|c|}{ PwC named in case } \\
\hline & & No & Yes & Total \\
\hline & No & 168 & 25 & 193 \\
\hline Settlements & & & & \\
\hline & Yes & 121 & 44 & 165 \\
\hline & & & & \\
\hline Total & & 289 & 69 & 358 \\
\hline
\end{tabular}

Pearson Chi-Square $=10.5575$ Probability $=0.001$

Table 6b Results of Chi-Square test showing ratio of Ernst \& Young Settlement to total settlement by all parties is above median.

\begin{tabular}{|c|c|c|c|c|}
\hline \multicolumn{4}{|c|}{ Ernst \& Young settling the case } \\
\hline & & No & Yes & Total \\
\hline \multirow{3}{*}{$\begin{array}{c}\text { \% Settlement above } \\
\text { median }\end{array}$} & No & 64 & 19 & 83 \\
\cline { 2 - 5 } & & & & \\
\cline { 2 - 5 } & Yes & 77 & 6 & 83 \\
\hline Total & & & & \\
\hline
\end{tabular}

Pearson Chi-Square $=6.5652$ Probability $=0.010$

Table 6c Results of Chi-Square test showing Deloitte settlement delay is above median.

\begin{tabular}{|c|c|c|c|c|}
\hline \multicolumn{5}{|c|}{ Deloitte settling in cases for above \$10 Million } \\
\hline \multirow{2}{*}{$\begin{array}{c}\text { Settlement Delay is above } \\
\text { median }\end{array}$} & No & 20 & 8 & 28 \\
\cline { 2 - 5 } & & & & \\
\cline { 2 - 5 } & Yes & 26 & 2 & 28 \\
\hline Total & & & & \\
\hline & & 46 & 10 & 56 \\
\hline
\end{tabular}

Pearson Chi-Square $=4.1387$ Probability $=0.042$ 